\title{
Determinants of National Saving in Ethiopia: Time Series Analysis
}

\author{
Edosa Kubsa Lebeta ${ }^{1, *}$, Debeli Chala Biyena ${ }^{2, *}$ \\ ${ }^{1}$ Economics Department, Bule Hora University, Bule Hora, Ethiopia \\ ${ }^{2}$ Forest and Rangeland Directorate, Ethiopian Biodiversity Institute, Addis Ababa, Ethiopia \\ Email address: \\ cchalabiyana@gmail.com (E. K. Lebeta), debelichala@gmail.com (D. C. Biyena) \\ ${ }^{*}$ Corresponding author
}

To cite this article:

Edosa Kubsa Lebeta, Debeli Chala Biyena. Determinants of National Saving in Ethiopia: Time Series Analysis. International Journal of Finance and Banking Research. Vol. 7, No. 3, 2021, pp. 67-75. doi: 10.11648/j.ijfbr.20210703.11

Received: May 17, 2021; Accepted: July 9, 2021; Published: July 15, 2021

\begin{abstract}
In poor countries like, Ethiopia national saving have a vital role for capital accumulation, which facilitate domestic investment and economic growth. Accordingly, this paper mainly investigates the covariate that determines national savings specifically in Ethiopia based on the time series data collected from year 1984-2016E.C. The main objective of the study is to identify trend of and the major covariates that determine national saving in Ethiopia. Five covariates (variables) have employed, namely national saving, real GDP, investment, deposit rate, and inflation rate. Autoregressive distributed lag (ARDL) approach to co-integration and error correction model (ECM) has applied to analyze the long run and short-run relationship between the explained and explanatory variables. The long-run model result revealed that, the Real Gross Domestic Product, investment, deposit rate, and inflation have shown a similar relationship. Accordingly, Real Gross Domestic product, investment, deposit and inflation rate, are significantly and positively correlated with national saving. However, in the short-run, except deposit rate all independent variables affect national saving positively. The error correction term has a coefficient of -100.66 which shows that there will be about $100.66 \%$ percent speed of adjustment toward long run equilibrium in each year when there is any imbalance in the short run. Finally, as the model result revealed, national saving responded to the real gross domestic product, investment and deposit rate on the theoretically expected manner, however not for the inflation rate. Then the paper recommends increasing an alternative to enhance performance of national saving by considering its contribution for economic growth and development of Ethiopia.
\end{abstract}

Keywords: National Saving, ARDL, ECM, and Ethiopia

\section{Introduction}

Different economics concepts concerning growth of economy have revealed that national saving is a significant component which finances investment, improves the level of productivity and economic growth of every country. Therefore, it would be essential to look at the determinants of national saving to completely recognize economic growth. National saving offers an important link \& connection between past, present and future economic growth of a country (Kazmi, 1993) as cited in [12]. Meaning that In poor countries like, Ethiopia national saving have a vital role for capital accumulation, which facilitate domestic investment and economic growth.
Saving is the most important factors of economic growth. It constitutes the basis for investment, capital formation, growth and development of the country. To move third world countries to the path of development, rate of savings must be enhanced. The household's savings contribute a major part of the national savings. It has been found that in any economy the household savings rate is a prime cause for the highs or lows economic development. For the developing countries including Ethiopian, the household savings rate is a decisive factor of influencing the overall economic scenario. [14]

An economic system must be able to produce capital if it is to satisfy the want and needs of its people. To produce capital, people must be willing to save, which release product for use elsewhere. When people save, they make funds available to others. When a business borrows these savings, 
new business and a service has created, plants and equipment are produced and new jobs become available, [11].

Mankiw puts the importance of allocation of economic resources, as the behavior of economic agents in the allocation of economic resources is a critical factor that exerts influence on the growth path of a country. One of such allocation issue is concerned with the inter-temporal allocation of income between consumption and saving. The behavior and determinants of such allocation decision are important to understand the mechanisms and interactions across aggregate consumption; saving, capital accumulation, and growth processes economic policies in most countries attempt to influence the level and growth of these variables to achieve growth in productivity and employment, macroeconomic stability and efficient resource allocation. The efficiency of such policies, however, depends on the nature and degree of influence that policies have on macroeconomic variables [5].

There is no doubt that economic growth is the main target of all countries all over the world including developed and developing countries. Among other things, growth in Real Gross Domestic Product (RGDP) is a good indicator of economic growth; higher RGDP implies higher income and a thus higher standard of living of course higher growth rate of GDP. One of the important ingredients of GDP is saving. Saving rates around the world are very widely practiced currently, on average East Asia saves more than $30 \%$ of gross national disposable income, while sub-Saharan Africa saves less than $15 \%$. According to [4], Ethiopia is falling in a sort of trap as it is not saving enough as a nation and just depending on foreign investment and other such means to boost its growth. He advised Ethiopia should focus on saving as a nation rather than depending on foreign investment and loans, which risks its growth potential. Therefore, to achieve five years of growth and transformation (GTP) and MDGs, Ethiopia has to increase the saving rate. Saving has a direct and positive relationship with GDP.

In developed economies, saving has a larger part in total output and its growth rate is high. Thus, it can be said that saving has a big contribution to the growth rate of an economy. The experience in developing countries in recent years has also demonstrated that achieving gains in real per capita incomes requires more saving. Nonetheless, saving in developing countries is significantly lower than in other countries and still too low to support a sustainable expansion in output and employment. When we come to Ethiopia, low saving has always been the dominant feature of the Ethiopian economy even after various reforms undertaken to encourage [4].

Most previous studies on saving were mainly concentrated on national saving and domestic saving. For example, according to [2] development economics have for several decades recognized the importance of national saving for economic growth in developing countries. However, the national saving level in Ethiopia is very low and little is known empirically about its patterns and determinants. So to fill this gap this study focuses on the determinants of national saving in Ethiopia that rely mostly on empirical studies that focus on other countries to provide possible explanatory variables in a savings equation as well as broad guidelines for the expected sign of the coefficients estimated. Therefore, this study aimed; to evaluate the impact of the main determinants of saving identified in the literature on national savings in Ethiopia and to suggest policies that could be used to increase the rate of national savings in the country.

\subsection{Objectives}

The general objective of this study is to identify the major factors that determine national saving in Ethiopian context. To achieve the above broad objective, the study has the following specific objectives:

a. To investigate trends and performance of national savings in Ethiopia;

b. To examine the long run and short-run determinants of national saving in Ethiopia;

\subsection{Hypothesis}

HO: There exists statistically significant relationship between national saving and its determinants.

H1: There exists statistically insignificant relationship between national saving and its determinants.

\section{Review of Literatures}

\subsection{Theoretical Literature}

Saving is abstaining from spending money and property for un-necessary, extravagance activity, set-aside money, and property for the future uncertainties and better use. Saving is important to human beings to lead for future life in a better way. Any person either poor or rich cannot.

Confidentially tell about the future happening. So, peoples have to set aside money and property left after consumption of current time. A human being is different from other animals by its thinking for tomorrow. Even there is a difference in culture and civilization from country to country; peoples save for themselves, the rest of their family and for the future generation.

Theories of Saving

\section{(i). The Traditional Theory of Saving}

The traditional theory of saving concentrated on two important issues as Edward 1995, cited in Metin Oz can K., 2000 points out:

a. The effect of higher savings on long-run growth;

b. The impact of an increase in domestic savings on investment;

There is a positive association between the rate of saving and the growth rate of income. The positive association, however, does not indicate causality and there is a possibility that those variables could be reflections of an underlying omitted third variable. The long-run growth rate of income has significantly determined by the domestic investment rate and the domestic saving rate. 
The domestic saving and the rate of investment are closely related; the correlation between these two variables is one of the indications of the limited nature of capital mobility across countries.

\section{(ii). The Neoclassical Theory}

The neoclassical theory suggests that during the transition between steady states, an increase in saving ratios generate higher growth only in the short-run. In the end, the equilibrium rate of growth has explained by structural and demographic variables. [6]

\section{(iii). Endogenous Theory}

The endogenous growth theory as suggested by Romer (1986) cited in [15] asserts that higher rates of savings and investment are essential in an economy thanks to their strong and positive relationship with the GDP growth rate. They add that increments in savings in association with increases in the population size increase the long-run rate of growth of an economy.

And also the theory of growth suggests that a permanent increase in growth rates can be determined by increased capital accumulation and achieved higher savings. If there is very limited international capital mobility, higher domestic saving results in higher investment and economic growth. However, this is valid only if investment and domestic savings are highly correlated.

\section{(iv). The Life Cycle Theory (LCM) Model}

The life cycle model (LCM) assumes that economic agents make sequential decisions to achieve a coherent goal using the currently available information as best they can. Utility maximizing agents postpone part of their current consumption and save it for consumption during retirement in a dynamic and uncertain environment, [1]. The permanent income hypothesis argues that consumption expenditure closely follows permanent income, instead of the current income of economic agents, [1]. From the perspective of national saving, the basic lifecycle framework implies that the growth rate of income and the age structure of the population are the main determinants of aggregate consumption and saving rate. The model predicts that the growth rate of income increases the lifetime resources available for the young age and net savers in the population, making a higher saving rate possible.

\subsection{Empirical Review}

Several empirical studies have done in developed and developing countries trying to point out the key variables that should considered when studying the national saving behavior. The following are some of the reviewed studies on national savings behavior.

The rate of saving, from a global perspective, has exhibited a downward trend over the past three decades. The oil-shocks and the subsequent recessions and declines in the growth rate constitute the main explanation behind such global variations in saving rates. The developing countries have registered a relatively lower rate of saving than the developed. However, among those developing countries those with fast economic growth rate registered significantly increase in the national saving. Whereas most regional economies either increased or maintained their saving performance, sub-Saharan African countries lost their ground in their both saving rate as well as growth rate performance. The region is unique in a sense that is saving rate has been not only low but also declining over the last three decades [1].

Dayal-Ghulati and Thiman examine empirical determinants of national savings for a sample of economies in South East Asia and Latin America over the period 19751995, they use panel-estimation to examine the relationship between national saving rates and policy and non-policy variables [3]. Their results indicate that fiscal policy, particularly social security arrangements influence national savings; macroeconomic stability and financial deepening also appear as important variables determining saving behavior in the two regions.

Tochukwu E. N. and Fetus D. E. examine the determinants of national saving in Nigeria [10]. They compare the estimation results of the error-correction model (ECM) with those of three conventional models: Partial adjustment, Growth rate, and Static models. They concluded that the error correction model (ECM) performs much better than the other models. Their results reveal that the saving rate rises with the level of disposable income but falls with the rate of growth of disposable income. The real interest rate on bank deposits has a significant negative impact on while public saving seems not to crowd out national savings. Furthermore, external terms of trade, inflation rate, and external debt service ratio have a positive impact on national saving.

Prema C. A. examines the determinants of national saving in the process of economic development, in the Indian experience [7]. He found that the saving rate rises with both the level and the rate of growth of disposable income. Prema C. A. found that real interest rate on Bank deposits has a significant positive impact but the magnitude of the impact is modest, public saving seems to crow out national saving, but less than proportionately [7]. Furthermore, the spread of banking facilities in the economy and inflation rate has a positive impact and changes in the external terms of trade a negative impact on national saving.

According to Ogren (2018) as cited in [13] studied the determinants of the saving behavior in 15 OECD countries, using panel data from 1995-2016. The result showed that factors such as uncertainty unemployment as precautionary savings and the intensity of fiscal policy are found to have a significant effect on the level of total household income. There are other determinants, like demographic factors which contribute less to the explanation of unemployment but not inflation of the level of saving.

The saving rate in Ethiopia has been very low and declined over time. During 1960-2003, the average domestic saving rate has been only 5.4 percent of GDP. Not only was the average saving rate has been low relative to income, but it also exhibits a declining trend. The average saving rate was about 14 percent of GDP during the period 1960/1-1974/75 
and declined to nearly 7 percent during the Dergue regime. On balance, what we end up having during the Dergue was not an increase in the saving and investment ratios compared with the previous regime. What we achieved during the Dergue was tremendous fluctuations, and the saving rate collapsed to about a mere 3.7 percent during 1991/2-2002/3.

The recent rate of saving is too low by the country's standard and relative to other developing countries. The economy witnessed a saving transition in 1974 that reduced the saving rate consistently leading a collapse of the national saving rate that has never managed to reverse. The trend has also made the economy increasingly dependent on external financing, with excessive exposure to external shocks, and delaying the necessary reforms to create conducive investment to the national sector and put the economy on the sustainable path of growth and financing. [1]

When we see the gross domestic savings, it was $13.86 \%$ of the GDP in the Imperial period, $6.68 \%$ in the Derg period and $5.13 \%$ in the current regime up to 2000 . The highest GDS to GDP ratio in the Imperial period was $15.32 \%$ in 1972 and the lowest was $12.53 \%$ in 1970 . These numbers are very high as compared to the numbers in the Derg period and the current government. In the Derg, the highest ratio was $12.47 \%$ in 1987 and the lowest was 2.83\&in 1994. In the current, until 2000 the highest rate was $7.73 \%$ in 1997 and the lowest was $0.9 \%$ in 1999 . These very low saving rates were experienced due to the reduction in the deposit interest rate by the National Bank of Ethiopia to reduce the liquidity of banks and to increase the consumption level in the Economy so that investors will be motivated to invest, to take advantage of this increased consumption.

\section{Methodology}

\subsection{Model Specification}

Having been motivated from the previous work of said [8]on the determinants of national saving in Jordan by using dependency rate, government saving, GDP growth rate, GDP per capita, Money/GDP, social security, real interest rate, inflation rate and terms of trade as explanatory variables the study investigates the effects on national saving rates of several policies. Beside, the study focused on non-policy variables, including government policies, macroeconomic stability, income, and financial variables as well as several life-cycle variables in Ethiopia.

In developing a saving model, it is difficult to include all the determinants of national saving because of the unavailability of all the data required and non-quant able of some determinants. The saving model includes the following explanatory variables in the form of multiple linear regression functions.

$$
\mathrm{GNSt}=\beta_{0}+\beta_{1} \mathrm{RGDP}_{\mathrm{t}}+\beta_{2} \mathrm{INV}_{\mathrm{t}}+\beta_{3} \mathrm{DR}_{\mathrm{t}}+\beta_{4} \mathrm{INF}_{\mathrm{t}}+\varepsilon \ldots
$$

Where GNS is the gross national saving, RGDP is a real gross domestic product, DR is deposit rate, INV is an investment, INF is the inflation rate and $\varepsilon$ is the error term that captures the potential dependent variables excluded from the model.

A time-series technique of co integration has employed to examine the long-run relationship among the variables. The study tests for the time-series properties of the variables as most economic variables are non-stationary at the level. In other words, Means and Variances are not constant. For valid estimation and inference has made, a set of non-stationary variables must be co integrated, which is a stationary linear combination of these variables that must exist. The commonly used augmented Dickey-Fuller (ADF) unit root tests for determining the variables' orders of integration was applied Autoregressive Distributed Lag (ARDL) Model is employed in carrying out the long-run relationship between the variables.

\subsection{Description of Variables and Expected Results}

The description of the variables entering the private saving model and the expected results has presented as follows:

Gross national Saving (GNS): is the sum of a nation's public and private savings. On the other hand, national saving equals a nation's income minus consumption and government expenditure and used as the dependent variable.

Real Gross Domestic Product (RGDP): An increase in RGDP has a positive effect on national saving. This is because an increase in RGDP leads to an increase in income. It has known from economic theories that as income increase the marginal propensity to consume out of the additional income decreases it leads to an increase in saving. Therefore, we expect that the sign for RGDP during regression is positive.

Inflation Rate: is measured by the changes in the consumer price index and used as a proxy for macroeconomic instability, which leads to uncertainty about future income. That is, people tend to save in an inflationary environment and a positive sign is expected. However, in the case of Ethiopia in an inflationary environment, people will not save in monetary terms rather buying other fixed assets and the researcher expects a negative relationship between inflation rate and national saving.

Investment: Investment is one of the major contributors to economic growth and development in both developed and developing countries and gross capital formation. Through investment, new technology can be adopted, employment opportunities can be created, incomes can grow and living conditions of the people can be improved. Investment, therefore, facilitates the way for a person to save more thus, ultimately lead to alleviation of poverty. [9] Therefore, the sign I expect here is positive.

Deposit rate: In deposit terminology, a term depot rate refers to the amount of money paid out an interest by a bank or financial institution on cash deposits. Example a deposit interest rate will often be paid for cash deposited into savings and money market accounts. Saving accounts earn a rather low rate of interest, but cash deposited in other certain 
account types are also paid a deposit rate by the bank and financial institution. In a sense, the deposit rate is the interest rate that banks pay the depositor for the use of their money for the period that the money is on deposit.

Random (Stochastic Error Term): It is a term, which includes other determinants, which could be both qualitative and quantitative variables that are not included in this specific model

\subsection{Data Type and Source}

A time-series data ranging from 1984 to 2016 has used in this study to show the extent of the relationship between national saving and its determinants both in the descriptive and econometric analysis.

All the data has gathered from secondary sources. Most of the data has taken from the Ethiopian economics Association (EEA) database and the research department of the national bank of Ethiopia (NBE). In addition, the quarterly bulletins and annual reports of commercial banks of Ethiopia (CBE), International financial statistic (IFS), the International monetary fund (IMF), World Bank and different bulletins has used as a source of data.

\section{Analysis and Results}

\subsection{Descriptive Data Analysis}

A descriptive data analysis has conducted using graphs for the variables to detect the movements in the value of national saving over time and to analyze the cause of movements.

Figure 1 depicts saving in Ethiopia was relatively low in the beginnings of 1980's than the later years. It has sharply increased from the year 1992-2000. After that, it started declining at the beginning of 2001, and in 2003 it recovers. In recent years, there is no much fluctuation in saving in Ethiopia. This decline and rise of saving in different years is the result of the impacts of varieties of economic variables, which affects saving in Ethiopia. For instance, the inflation rate around the year 2003 was nearly 15, which was one of the highest inflationary levels in Ethiopia. This might be one of the causes of a decline in saving in Ethiopia in these periods. In 2011/2012 saving in Ethiopia was relatively high which might be related to the highest levels of RGDP, Saving rate, and level of investment which is $11.5,12$ and 10 respectively.

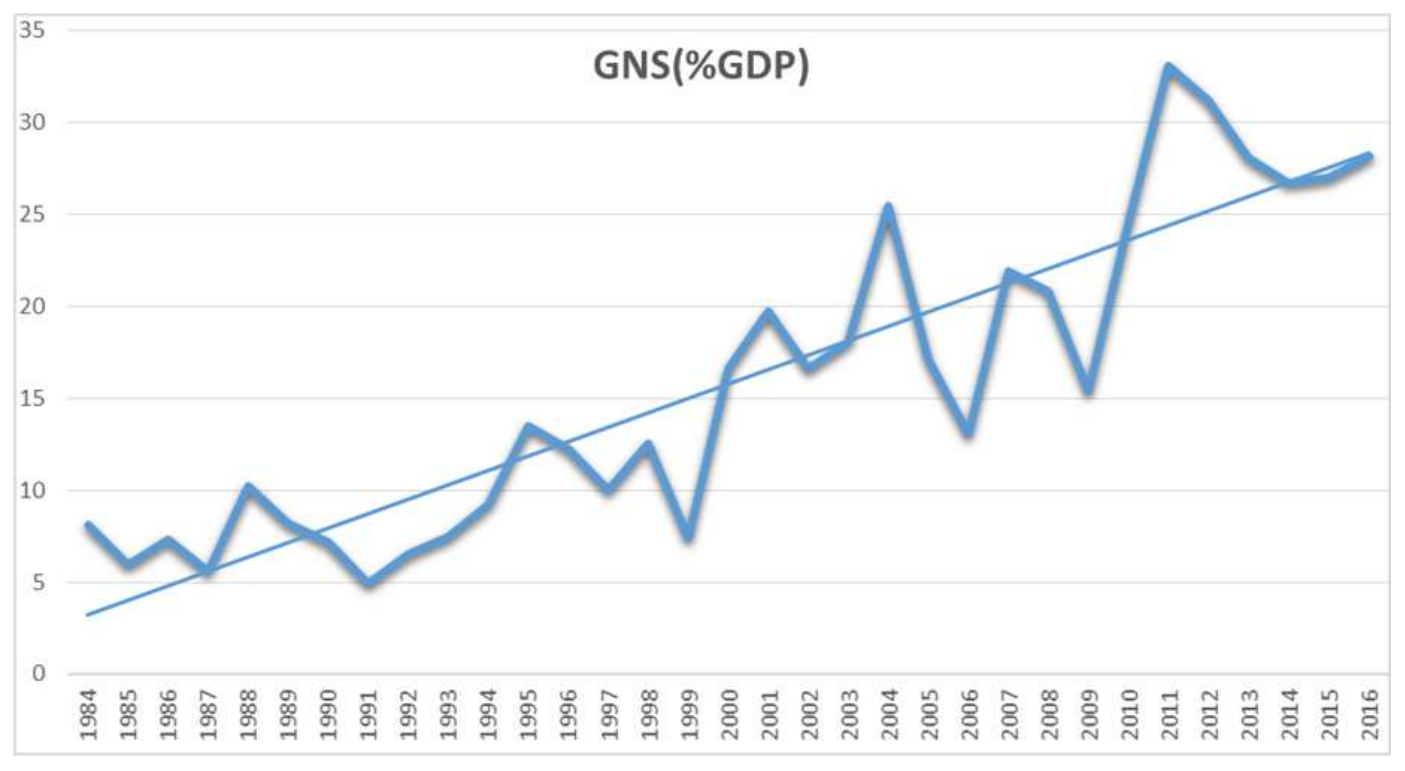

Source: own sketch based on NBE data (2017).

Figure 1. Trends of National Saving In Ethiopia from 1984 -2016.

\subsection{Econometric Analysis}

\subsubsection{Unit Root Test}

To analyze the relationship between the variables, the study tests for the time-series properties of the variables that enter the national saving model by employing the unit root test using the Augmented Dickey-Fuller (ADF). The null hypothesis is that there is a unit root in our observed time series against the alternative hypothesis that the process is stationary.

Table 1. Results of Augmented Dickey-Fuller (ADF) Unit Root Test.

\begin{tabular}{|c|c|c|c|c|c|c|}
\hline Variable & Null hypothesis & Test statistics & $1 \%$ critical value & $5 \%$ critical value & $10 \%$ critical value & order of integration \\
\hline LNNS & NS has a unit root & -8.031407 & -4.28458 & -3.562882 & -3.215267 & I (1) \\
\hline LNRGDP & RGDP has a unit root & -5.926189 & -4.28458 & -3.562882 & -3.215267 & I (1) \\
\hline LN INV & INV has a unit root & -7.845796 & -4.28458 & -3.562882 & -3.215267 & I (1) \\
\hline DR & DR has a unit root & -4.671675 & -3.661661 & -2.960411 & 2.61916 & $\mathrm{I}(0)$ \\
\hline INF & INF has a unit root & -3.914848 & -3.65373 & -2.95711 & -2.617434 & $\mathrm{I}(0)$ \\
\hline
\end{tabular}

Source: author computation using review 9. 
All variables are stationary at all levels of critical values. i.e., at $1 \%, 5 \%$ and $10 \%$ respectively.

The presence of a unit root implies that the time series under investigation is non-stationary, while the absence of a unit root shows that the stochastic process is stationary. The test has shown that national saving, real gross domestic product, and investment are not stationary at a level, while deposit rate and inflation are stationary at a level. To make the variables stationary their first difference is taken. At the first difference national saving, real gross domestic product (RGDP) and investment (GCF) have become stationary.

Table 2. Results of Bounds Tests for the Existence of Cointegration.

\begin{tabular}{lll}
\hline ARDL Bounds Test & \\
\hline Date: 06/10/17Time: 12:08 & & \\
\hline Sample: 1986 2015 & & \\
\hline Included observations: $\mathbf{3 0}$ & & \\
\hline Null Hypothesis: No long-run relationships exist & K \\
\hline Test Statistic & Value & $\mathbf{4}$ \\
\hline F-statistic & $\mathbf{3 . 8 0 4 4 7 6}$ & \\
\hline Critical Value Bounds & & I1 Bound \\
\hline Significance & $\mathbf{I 0}$ Bound & 3.01 \\
\hline $10 \%$ & 1.9 & 3.48 \\
$5 \%$ & 2.26 & 3.9 \\
$2.5 \%$ & 2.62 & 4.44 \\
\hline
\end{tabular}

Source: Computed by the author using review 9 .

\subsubsection{Cointegration Tests}

As is depicted in table 2 above, the calculated F statistics (3.804476) are higher than the upper bound critical values at $5 \%$ and $10 \%$ level of significance respectively. This implies that the null hypothesis of no long-run relationship is rejected; rather accept the alternative hypothesis (there is a long-run relationship) based on the critical values at $5 \%$ and $10 \%$ level of significance. Therefore, there is a co-integration relationship between the variables in the long run.

\subsubsection{The Long Run ARDL Model}

After I checked the existence of long-run co-integration relations among the variables, the next step is running the appropriate ARDL model to find out the long-run coefficients, which is reported in table 3 below.

Table 3. The results of the long-run saving equation, review 9 results.

\begin{tabular}{llll}
\hline Long Run Coefficients & & & \\
\hline Variable & Coefficient & Std. Error & t-Statistic \\
\hline LNRGDP & 0.158330 & 0.088373 & 1.791604 \\
LNINV & 0.793479 & 0.101694 & 7.802588 \\
DR & 0.019353 & 0.006812 & 2.840895 \\
INFL & 0.022617 & 0.007905 & 0.0870 \\
\hline
\end{tabular}

Source: Computed by the author using eview9.

\section{$\mathrm{LNNS}=0.158330 \mathrm{LNRGDP}+0.793479 \mathrm{LNINV}+0.019353 \mathrm{DR}+0.022617 \mathrm{INFL}$}

The RGDP, DR, INV and INF are significantly affecting the national saving at a common level of significance $(1 \%$, $5 \%$ and, $10 \%$ ) in the long run. The relationship between national saving and the real gross product is positive. Other things remain constant as RGDP increases by one percent change national saving increases by 0.158330 percent. Investment is also positively affecting national saving, as investment increases by one percent change national saving increase by 0.793479 percent. Like the above two variables deposit rate and inflation rate are positively affecting the national saving of Ethiopia. Other things remain constant, as the deposit rate increases by one percent change, national saving increases by 1.9 percent. Other factors remain the same as inflation increase by one percent change, national saving increase by 2.26 percent. Generally, except for the inflation rate all variables have expected sign. While many theoretical and empirical studies confirm the negative impact of inflation on saving, the results of this study show that there is not enough evidence to confirm the positive effect of inflation on saving. 
Table 4. The results for the Short-run national saving equation; reviews 9 Result.

\begin{tabular}{lllll}
\hline Cointegrating Form & & & & Prob. \\
\hline Variable & Coefficient & Std. Error & t-Statistic & 0.0370 \\
\hline D (LNRGDP) & 1.526727 & 0.687598 & 2.220378 & 0.0000 \\
D (LNINV) & 0.798696 & 0.142014 & 5.624076 & 0.4090 \\
D (DR) & -0.001545 & 0.001836 & -0.841667 & 0.0147 \\
D (DR (-1)) & -0.011433 & 0.004318 & -2.647849 & 0.0068 \\
D (INFL) & -0.022766 & 0.007626 & 2.985436 & 0.0000 \\
CointEq (-1) & -1.006574 & 0.124084 & -8.112020 & \\
\hline
\end{tabular}

Cointeq $=$ LNNSV $-(0.1583 *$ LNRGDP $+0.7935 *$ LNINV $+0.0194 *$ DR $-0.0226 *$ INFL $)$

Source: Computed by the author using eview9.

\subsubsection{Short Run Error Correction Model Using ARDL Approach}

When we arrange the above short-run equation the sign can be changed but not in magnitude, i.e. By equating the equation with zero.

$$
\text { LNNS }=0.1583 * \text { LNRGDP }+0.7935 * \text { LNINV }-0.0194 * \text { DR }-0.0226 * \text { INFL }
$$

In the long run, the RGDP, INV, and INF are significantly affecting national saving at a common level of significance $(1 \%, 5 \%$ and $10 \%)$ in the short run. Unlike the long run, the deposit rate affects national saving negatively but significantly in the short run. Moreover, the coefficient of the error term (ECM-1) implies that the deviation from the longrun equilibrium level of national saving in the current period is corrected by $100.66 \%$ in the next period to bring back equilibrium when there is a shock to a steady-state relationship. Shortly in the next period national saving is corrected by $100.66 \%$ to its long-run equilibrium.

\subsubsection{Diagnostic Tests on the Residual of ARDL Model Estimation}

This is to assess the validity of the model using different tests.

Breusch-Godfrey Test for Serial Correlation was conducted using the Breusch-Godfrey LM Test and the null hypothesis of no serial correlation was tested against the alternative hypothesis of serial correlation. The result in table 5 indicates that the residuals of the model have no serial correlation, as indicated by the given probability value at all levels of significance.

Breusch-Pagan-Godfrey test for Heteroskedasticity has conducted based on the null hypothesis of homoscedasticity, against the alternative of Heteroskedasticity. The result in table 5 shows that the residuals of the model are homoscedastic at all levels of significance, as indicated by the probability value.

Jarque-Bera Normality test - from table 5 tests the null hypothesis that the residuals of the estimated model are normal against an alternative that the residuals are not normal, depicts a probability of 0.55 . This is an indication that the null hypothesis has not rejected and that the residuals are normal.

Ramsey RESET test has carried out to ascertain if the estimated model has properly specified. Mis-specification may include the inclusion of an irrelevant variable, exclusion of relevant variables, wrong functional form, etc. The test is based on the null hypothesis of a properly formulated model.
The result from the test indicates that the model is not misspecified as indicated by the probability value of the Fstatistics.

Table 5. Post Estimation Tests.

\begin{tabular}{lll}
\hline Tests & Test Statistics & Probability \\
\hline Breusch-Godfrey serial & & \\
correlation LM test & 0.31 & 0.58 \\
Breusch-Pagan-Godfrey & & \\
Heteroskedasticity Test & 0.34 & 0.56 \\
Jarque-Bera Normality test & 1.16 & 0.55 \\
Ramsey RESET Test & 0.87 & 0.35 \\
\hline
\end{tabular}

\section{Conclusion}

The main objective of this study is to analyze the trend and determinants of national savings in Ethiopia during the specified study period. To determine the long run and shortrun relationship among the variables, the Autoregressive Distributed Lag (ARDL) model has applied. Before applying the ARDL model, all the covariates/variables are tested for their time-series properties (stationary properties) using the ADF test. Accordingly, based on econometric model result, the study concludes that, national saving responded to the real gross domestic product, investment and deposit rate in line of its theoretically expected manner, however, not for the inflation rate. On the other hand, RGDP, deposit rate, and investment are the most important covariates significantly affect national saving in Ethiopia in relative to other mentioned determinant covariates of national saving. Finally, the study concludes national saving varied positively with all variables in periods, i.e. in long run and short run.

\section{Recommendations}

Based on the study result and main conclusions the following recommendations has forwarded as an alternative to enhance performance of national saving by considering its contribution for economic growth and development of Ethiopia; 
a) National investment and national savings have a positive relationship in both periods. So, to increase national saving the central bank of Ethiopia should fulfill all the necessary conditions for both public and private saving.

b) Government policy towards investment should be conducive for both as domestic and foreign investors, which are the main source of high volume saved income.

c) Deposit rate and national savings have a significant impact. This is due to people choosing to save more when the deposit rate increases rather than consuming. Therefore, the Ethiopia central bank should set attractive deposit rate in line it is economically meaning full.

d) Both in the long run and short-run real gross product and national saving have a positive correlation.
Therefore, the Government should improve production of national output through productive investment expansion.

\section{Availability of Data}

Dataset surveyed in this study is available from the corresponding author on reasonable request.

\section{Contributions}

The authors worked jointly to come up with the paper. Both authors read and approved the final manuscript.

\section{Competing Interests}

The authors declare that they have no competing interests.

\section{Appendix}

Table 6. The Original Long Run Model Using the ARDL Approach.

\begin{tabular}{|c|c|c|c|c|}
\hline \multicolumn{5}{|c|}{ Dependent Variable: LNNSV } \\
\hline \multicolumn{5}{|l|}{ Method: ARDL } \\
\hline \multicolumn{5}{|c|}{ Date: 06/10/17Time: 12:00 } \\
\hline \multicolumn{5}{|c|}{ Sample (adjusted): 19862015} \\
\hline \multicolumn{5}{|c|}{ Included observations: 30 after adjustments } \\
\hline \multicolumn{5}{|c|}{$\begin{array}{l}\text { Maximum dependent lags: } 2 \text { (Automatic selection) } \\
\text { Model selection method: Akaike info criterion (AIC) }\end{array}$} \\
\hline \multicolumn{5}{|c|}{ Dynamic regressors (2 lags, automatic): LNRGDP LNINV DR INFL } \\
\hline \multicolumn{5}{|l|}{ Fixed regressors: $\mathrm{C}$} \\
\hline \multicolumn{5}{|c|}{ Number of models evaluated: 162} \\
\hline \multicolumn{5}{|c|}{ Selected Model: ARDL $(1,1,0,2,0)$} \\
\hline Variable & Coefficient & Std. Error & t-Statistic & Prob.* \\
\hline LNNSV (-1) & 0.002734 & 0.132813 & 0.020585 & 0.9838 \\
\hline LNRGDP & 1.461692 & 0.754815 & 1.936491 & 0.0664 \\
\hline $\operatorname{LNRGDP}(-1)$ & -1.381570 & 0.662153 & -2.086481 & 0.0493 \\
\hline LNINV & 0.841014 & 0.230537 & 3.648069 & 0.0015 \\
\hline DR & -0.001669 & 0.001948 & -0.856616 & 0.4013 \\
\hline DR (-1) & 0.009310 & 0.003286 & 2.833415 & 0.0100 \\
\hline $\mathrm{DR}(-2)$ & 0.010986 & 0.004803 & 2.287465 & 0.0326 \\
\hline INFL & 0.022506 & 0.007872 & 2.858898 & 0.0094 \\
\hline $\mathrm{C}$ & 0.414693 & 1.755011 & 0.236291 & 0.8155 \\
\hline R-squared & 0.973836 & Mean dependent var & 10.90076 & \\
\hline Adjusted R-squared & 0.963869 & S. D. dependent var & 0.747508 & \\
\hline S. E. of regression & 0.142088 & Akaike info criterion & -0.821414 & \\
\hline Sum squared resid & 0.423969 & Schwarz criterion & -0.401055 & \\
\hline Log-likelihood & 21.32121 & Hannan-Quinn criteria. & -0.686938 & \\
\hline F-statistic & 97.70354 & Durbin-Watson stat & 2.186761 & \\
\hline Prob (F-statistic) & 0.000000 & & & \\
\hline
\end{tabular}

*Note: p-values and any subsequent tests do not account for model selection. 
Table 7. Co-integration Test Results.

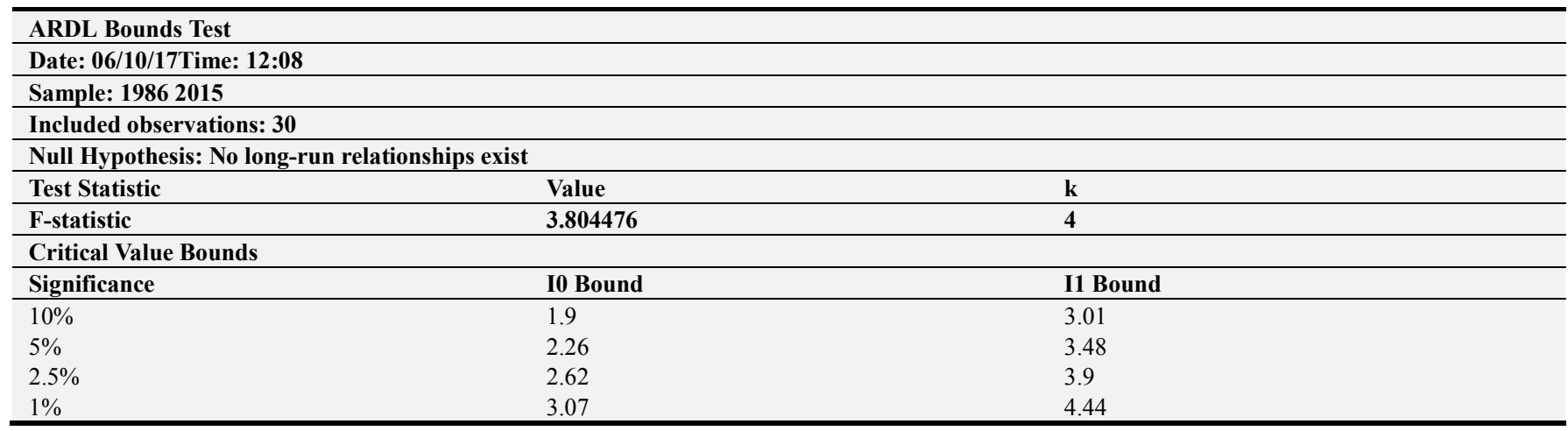

Table 8. ARDL Co-integration and Long Run Form.

\begin{tabular}{|c|c|c|c|c|}
\hline \multicolumn{5}{|c|}{ Dependent Variable: LNNSV } \\
\hline \multicolumn{5}{|c|}{ Selected Model: ARDL $(1,1,0,2,0)$} \\
\hline \multicolumn{5}{|c|}{ Date: 06/10/17Time: 12:09 } \\
\hline \multicolumn{5}{|c|}{ Sample: 19842016} \\
\hline \multicolumn{5}{|c|}{ Included observations: 30} \\
\hline \multicolumn{5}{|c|}{ Co-integrating Form } \\
\hline Variable & Coefficient & Std. Error & t-Statistic & Prob. \\
\hline D (LNRGDP) & 1.526727 & 0.687598 & 2.220378 & 0.0370 \\
\hline D (LNINV) & 0.798696 & 0.142014 & 5.624076 & 0.0000 \\
\hline $\mathrm{D}(\mathrm{DR})$ & -0.001545 & 0.001836 & -0.841667 & 0.4090 \\
\hline $\mathrm{D}(\mathrm{DR}(-1))$ & -0.011433 & 0.004318 & -2.647849 & 0.0147 \\
\hline $\mathrm{D}$ (INFL) & 0.022766 & 0.007626 & 2.985436 & 0.0068 \\
\hline CointEq (-1) & -1.006574 & 0.124084 & -8.112020 & 0.0000 \\
\hline \multicolumn{5}{|c|}{ Cointeq $=$ LNNSV $-(0.1583 *$ LNRGDP $+0.7935 *$ LNINV $+0.0194 *$ DR $+0.0226 * I N F L)$} \\
\hline \multicolumn{5}{|c|}{ Long Run Coefficients } \\
\hline LNRGDP & 0.158330 & 0.088373 & 1.791604 & 0.0870 \\
\hline LNINV & 0.793479 & 0.101694 & 7.802588 & 0.0000 \\
\hline DR & 0.019353 & 0.006812 & 2.840895 & 0.0095 \\
\hline INFL & 0.022617 & 0.007905 & 2.861228 & 0.0091 \\
\hline
\end{tabular}

\section{References}

[1] Abu Girma, (2004), on the determinants of domestic saving in Ethiopia, paper presented on the second international conference on the Ethiopian economy, EEA, Ethiopia.

[2] Ademe Ayalew. "Determinants of domestic saving in Ethiopia: An autoregressive distributed lag (ARDL) bounds testing approach", Journal of Economics and International Finance, 2013.

[3] Dayal-Ghulati and Thiman, (1997), saving in South East Asia and Latin America compared: searching for policy lessons, IMF.

[4] Ethiopian Economics Association, (2001/20012), the annual report on the Ethiopian economy, Addis Ababa, Ethiopia.

[5] Mankiew, N. G. (2000), Macroeconomics, $2^{\text {nd }}$ edition, Harvard University.

[6] Metain Ozcan Kilvicim, (2000), Determinants of national saving in the Arab countries Iran and Turkey Ankar, Turkey.

[7] Prema Chandra Athukroala, (2003), determinants of national saving in India, Australian national university, Canberra, Australia.
[8] Said Hallaq, (2003), determinants of national saving in Jordan, Ibid, Jordan.

[9] Simeneh Zewdu, (2006), Determinants of national investment in Ethiopia, Addis Ababa, Ethiopia.

[10] Tochukwu E. Nwachukwu and Fastus D. Egwaikhide, (2007), an error-correction model of the determinants of saving in Nigeria, Ibadan University, Nigeria.

[11] Easterly, William. 2003. "Can Foreign Aid Buy Growth?" Journal of Economic Perspectives, 17 (3): 23-48.

[12] Muhammad imran khan, jian-zhou teng, muhammad kamran khan, muhammad nauman, arshad ullah jadoon-(2017), determinants of national saving: evidence from south asian countries.

[13] Joseph basa bose (2020) empirical analysis of the domestic saving behaviour in rwanda. masters thesis.

[14] Temam gebu and feleke solomon, (2018), determinants of saving among rural households in ethiopia: the case of wolaita and dawro zone, snnpr. international journal of advanced research.

[15] Vivian nagawa, francis wasswa and edward bbaale, (2020), determinants of gross domestic savings in uganda: an autoregressive distributed lag (ardl) approach to cointegration. journal of economic structures. 